Tohoku J. Exp. Med., 2006, 208, 251-254

\title{
Nasal Obstruction as a Common Side-Effect of Sildenafil Citrate
}

\author{
A. Faruk Kiroglu, Hasmet Bayrakli, ${ }^{1}$ Koksal Yuca, Hakan Cankaya \\ and MUZAFFER KIRIS \\ Department of Otolaryngology, Yüzüncü Yıl University, School of Medicine, \\ Van, Turkey, and \\ ${ }^{I}$ Clinic of Urology, Zonguldak State Hospital, Zonguldak, Turkey
}

\begin{abstract}
Kiroglu, A.F., Bayrakli, H., Yuca, K., Cankaya, H. and Kiris, M. Nasal Obstruction as a Common Side-Effect of Sildenafil Citrate. Tohoku J. Exp. Med., 2006, 208 (3), 251-254 - Sildenafil citrate is an effective oral drug for erectile dysfunction. The main action of sildenafil is the enhancement of the effect of nitric oxide (NO) by inhibiting the cyclic guanosine monophosphate (cGMP)-specific phosphodiesterase-5 (PDE-5), an enzyme responsible for degradation of cGMP. NO is also present in the nasal mucosa and is responsible for vasodilation causing congestion and nasal obstruction. The aim of this study was to detect the effect of sildenafil on nasal mucosa in terms of nasal obstruction. A total of 16 patients presented to urology clinic suffering from impotence and medicated with sildenafil were included in the study. Before and after oral administration of $50 \mathrm{mg}$ sildenafil, in all of the patients the nasal patency was examined by active anterior rhinomanometry (a method of assessing nasal resistance) using air pressure of 150 Pascal. In addition, all patients were asked about their sensation of nasal patency to detect the symptomatic nasal obstruction. There was a significant decrease in nasal air flow values $\left(\mathrm{cm}^{3} / \mathrm{s}\right)(p<0.05)$. Except for three cases, all patients indicated that they had the sensation of nasal obstruction after the use of sildenafil $(p<0.05)$. Nasal obstruction is a common complaint for the patients using Sildenafil. —— Sildenafil; nasal patency; obstruction; rhinomanometry

(C) 2006 Tohoku University Medical Press
\end{abstract}

Sildenafil citrate (Viagra ${ }^{\circledR}$, Pfizer Inc., New York, NY, USA) is the first oral agent to be introduced for the management of erectile dysfunction. During sexual stimulation nitric oxide (NO) is released in the corpus cavernosum. NO activates the guanylate cyclase and results in increased levels of cyclic guanosine monophosphate (cGMP) from guanosine monophosphate (GMP). cGMP is broken down by phosphodiesterase-5 (PDE-5). Sildenafil, as a potent and selective inhibitor of the cGMP-specific PDE-5 enzyme, relaxes the smooth muscle in the corpus cavernosum, and allows greater inflow of blood, thereby causing erection (Boolell et al. 1996). Sildenafil is rapidly

Received September 5, 2005; revision accepted for publication January 17, 2006.

Correspondence: A. Faruk Kiroglu, Yüzüncü Yıl Unıversity, Arastirma Hastanesi, KBB Anabilim Dali, 65200, Van/ Turkey.

e-mail: fkiroglu@email.com

This paer was presented in the 20th Congress of the European Rhinologic Society and 23rd International Symposium on Infection and Allergy of the Nose, June 18-25, 2004, Istanbul, Turkey. 
absorbed with maximal plasma concentrations within 1 hour after oral intake and has a mean terminal half-life of 3 to 5 hours (Goldtein et al. 1988). NO regulates a variety of cellular and tissue functions, and is present in orally exhaled air (Gustafsson et al. 1991) but higher levels are found in the human nasal airways (Alving et al. 1993), especially in the paranasal sinuses (Lundberg et al. 1995). As a biologic mediator serving many functions, NO is present in nasal cavities and paranasal sinuses (Lundberg 1996). In addition to human corpus cavernosum smooth muscle, PDE-5 is also found in other tissues including vascular, visceral smooth muscle, and skeletal muscle (Moreira et al. 2000). In keeping with the known functions of NO as a vasodilatator in the pulmonary and systemic vascular beds (Wallis et al. 1999), NO could potentially cause vasodilation in nasal cavity.

Rhinomanometry is a method of assessing nasal resistance, which represents the obstruction to airflow through the nasal passages. Nasal resistance is calculated by measuring the flow through the nose and also the pressure of force required to cause the airflow. Rhinomanometry measures the air pressure and the rate of airflow in the nasal airway during respiration. We determined changes in nasal patency in patients taking Sildenafil by anterior active rhinomanometry.

\section{Materials and Methods}

After ethical approval was obtained from Yuzuncu Yil University Faculty of Medicine ethical committee, patients presented to urology clinic suffering from impotence and medicated with sildenafil were included in the study. The written permission was taken from all patients. A total of 16 patients with no history of previous nasal surgery, any nasal medication, clinical evidence of present rhinitis, gross septal deviation were included in the study. The median age was 58 years (range 50 to 65 years). Before the administration of sildenafil all subjects were evaluated by anterior active rhinomanometry (Hortmann $^{\circledR}$, Rhinomodule 180, Neckartenzlingen, Germany) at 150 Pascal (Pa). After one hour of administration of $50 \mathrm{mg}$ sildenafil, rhinomanometric measurement was repeated. In addition, all patients were asked about their sensation of nasal patency to detect the symptomatic nasal obstruction. Statistically the results were evaluated using paired $t$-test and chi-square test.

\section{Results}

Following the administration of sildenafil, there was a significant decrease in nasal air flow values $\left(\mathrm{cm}^{3} / \mathrm{s}\right)$ at $150 \mathrm{~Pa}(p<0.001)$. The mean air flow value was $115.25 \pm 96.14$ (Table 1). Except for three cases, all patients indicated that they had the sensation of nasal obstruction after the use of sildenafil $(p<0.05)$ (Table 1).

\section{Discussion}

Sildenafil is a specific PDE-5 inhibitor that facilitates erection by the inhibition of cGMP breakdown in the corpus cavernosum (Boolell et al. 1996). NO is normally found in nasal cavity in very high concentrations (Lundberg et al. 1995), and NO has been proposed as a marker in inflammatory diseases of the upper airways (Lundberg 1996). Immunohistochemical techniques have shown strong staining for inducible NO synthase in the epithelial cells of turbinates (Rosbe et al. 1996). Some authors suggest that NO synthase is located within the granules of human nasal mucosal mast cells (Bacci et al. 1994).

$\mathrm{NO}$ is a potent biological mediator and it was initially described as an endothelium derived relaxing factor due to its action as a vasodilatator. Also NO regulates the mucociliary function in the nasal airway. Therefore, children with cystic fibrosis and Kartagener's syndrome were found to have very low or absent levels of NO (Lundberg et al. 1994; Dotsch et al. 1996).

There have been several studies identifying the presence of three isoforms of NO synthase, but the reports show different results according to the subjects and analytic methods (Oh et al. 2003). Ferguson and Eccles reported that nasal concentration of NO is not related to the total nasal airway resistance as they measured by posterior rhinomanometry (Ferguson and Eccles 1997)

Motamed et al. (2003) first assessed the effect of sildenafil on nasal patency on five patients. They have used a Youlten flowmeter for their measurements and have found reduced nasal 
TABle 1. Patients' nasal airflow values and presence of sensation of nasal obstruction

\begin{tabular}{|c|c|c|c|}
\hline \multirow{2}{*}{ Patient no. } & \multicolumn{2}{|c|}{ Nasal air flow $\left(\mathrm{cm}^{3} / \mathrm{s}\right)$ at $150 \mathrm{~Pa}(\mathrm{~A})$} & \multirow{2}{*}{$\begin{array}{l}\text { Sensation of nasal } \\
\text { obstruction (B) }\end{array}$} \\
\hline & Before & After & \\
\hline 1 & 95 & 90 & - \\
\hline 2 & 196 & 181 & - \\
\hline 3 & 59 & 28 & + \\
\hline 4 & 227 & 35 & + \\
\hline 5 & 226 & 167 & + \\
\hline 6 & 59 & 16 & + \\
\hline 7 & 59 & 57 & - \\
\hline 8 & 280 & 35 & + \\
\hline 9 & 388 & 274 & + \\
\hline 10 & 290 & 162 & + \\
\hline 11 & 394 & 225 & + \\
\hline 12 & 154 & 92 & + \\
\hline 13 & 481 & 149 & + \\
\hline 14 & 594 & 388 & + \\
\hline 15 & 450 & 373 & + \\
\hline 16 & 288 & 129 & + \\
\hline
\end{tabular}

(A): $(p<0.01) t$-test.

(B): $(p<0.05)$ chi-square test.

patency after the administration of sildenafil. The present study is the second report on the effect of sildenafil on nasal patency, but we used a different method of anterior active rhinomanometry. We thus confirmed the findings reported by Motamed et al. (2003).

In our study three cases had mild decrease in nasal air flow values compared with the other patients and these three patients felt no change in the sensation of nasal obstruction after the use of sildenafil. We do not know the reason exactly, but nasal obstruction is not seen in all patients using Sildenafil (Moreira et al. 2000).

In conclusion, the present study suggests that patients using sildenafil may complain of nasal obstruction.

\section{References}

Alving, K., Weitzberg, E. \& Lundberg, J.M. (1993) Increased amount of nitric oxide in exhaled air of astmatics. Eur. Respir. J., 6, 1368-1370.

Baccı, S., Arbi-Riccardi, R., Mayer, B., Rumio, C. \& BorghiCirri, M.B. (1994) Localisation of nitric oxide synthase immunoreactivity in mast cells of human nasal mucosa.
Histochemistry, 102, 89-92.

Boolell, M., Allen, M.J., Ballard, S.A., Gepi-Attee, S., Muirhead, G.J., Naylor, A.M., Osterloh, I.H. \& Gingell, C. (1996) Sildenafil: an orally active type 5 cyclic GMPspecific phosphodiesterase inhibitor for the treatment of penile erectile dysfunction. Int. J. Impot. Res., 8, 47-52.

Dotsch, J., Demirakca, S., Terbrack, H.G., Huls, G., Rascher, W. \& Kuhl, P.G. (1996) Airway nitric oxide in asthmatic children and patients with cystic fibrosis. Eur. Resp. J., 9, 2537-2540.

Ferguson, E.A. \& Eccles, R. (1997) Relationship between nasal nitric oxide concentration and nasal airway resistance. Rhinology, 35, 120-123.

Goldtein, I., Lue, T.F., Padma-Nathan, H., Rosen, R.C., Steers, W.D. \& Wicker, P.A. (1988) Oral sildenafil in the treatment of of erectile dysfunction. N. Eng. J. Med., 338, $1397-1404$

Gustafsson, L.E., Leone, A.M., Persson, M.G., Wiklund, N.P. \& Moncada, S. (1991) Endogenous nitric oxide is present in the exhaled air of rabbits, guinea pigs and humans. Biochem. Biophys. Res. Commun., 181, 852-857.

Lundberg, J.O., Weitzberg, E., Nordvall, S.L., Kuylenstierna, R., Lundberg, J.M. \& Alving, K. (1994) Primarily nasal origin of exhaled nitric oxide and absence in Kartagener's syndrome. Eur. Resp. J., 7, 1501-1504.

Lundberg, J.O., Farkas-Szallasi, T., Weitzberg, E., Rinder, J., Lidholm, J., Anggaard, A., Hokfelt, T., Lundberg, J.M. \& Alving, K. (1995) High nitric oxide production in human paranasal sinuses. Nat. Med., 1, 370-373.

Lundberg, J.O. (1996) Airborne nitric oxide: inflammatory marker and aerocrine messenger in man. Acta Phyysiol. 
Scand., 157, 1-27.

Moreira, S.G., Jr., Brannigan, R.E., Spitz, A., Orejuela, F.J., Lipshultz, L.I. \& Kim, E.D. (2000) Side-effect profile of sildenafil citrate (Viagra) in clinical practice. Urology, 56, 474-476.

Motamed, M., Sandhu, D. \& Murty, G.E. (2003) Sildenafil and nasal obstruction. J. Otolaryngol., 32, 259-262.

Oh, S.J., Min, Y.G., Kim, J.W., Lee, S.J. \& Jarin, P.R. (2003) Expression of nitric oxide synthases in nasal mucosa from a mouse model of allergic rhinitis. Ann. Otol. Rhinol.
Laryngol., 112, 899-903.

Rosbe, K.W., Mims, J.W., Prazma, J., Petrusz, P., Rose, A. \& Drake, A.F. (1996) Immunohistochemcal localisation of nitric oxide synthase activity in upper respiratory epithelium. Laryngoscope, 106, 1075-1079.

Wallis, R.M., Corbin, J.D., Francis, S.H. \& Ellis, P. (1999) Tissue distribution of phosphodiesterase families and the effects of sildenafil on tissue cyclc nucleotides, platelet function and the contractile responses of trabeculae camaae and aortic rings in vitro. Am. J. Cardiol., 83, 3C-12C. 